\title{
THE ASSOCIATION OF FAMILY SUPPORT IN FULFILLING HEALTHY NUTRITIOUS FOODS, PROTEIN AND MICRONUTRIENT INTAKE WITH HEMOGLOBIN LEVELS AMONG ELDERLY
}

\author{
Luberta Ebta Wiyani ${ }^{1 *}$, Diffah Hanim ${ }^{2}$, Dono Indarto ${ }^{2,3}$ \\ ${ }^{1}$ Master Program of Nutritional Sciences, Universitas Sebelas Maret, Surakarta, Indonesia \\ ${ }^{2}$ Postgraduate Program of Nutritional Sciences, Universitas Sebelas Maret, Surakarta, Indonesia \\ ${ }^{3}$ Department of Physiology, Universitas Sebelas Maret, Surakarta, Indonesia \\ *E-mail: luberta.rd@gmail.com
}

\begin{abstract}
The elderly usually accompanied by many impairments due to decline in organ functioning which have a great impact on their daily intake and leads to anemia. Many elderlies also have mobility impairment which make them become more dependent and need supports from their family. The aim of this study is to investigate the relationship of family support, the daily intake of protein, iron, vitamin $\mathrm{C}$ with hemoglobin levels in elderly. This observational analytic study with cross-sectional design was performed in 185 elderlies aged 60-79 years determined using the OpenEpi program. Subjects collected by simple random sampling from chosen Posyandu in Klaten and Sragen districts. The data on daily intake and family support in fulfilling healthy nutritious foods were collected by using a 2x24-hour food recall form and a modified questionnaire from Hanim's study. Hemoglobin levels were measured from venous blood using Cyanmethhemoglobin method. The data were analyzed using the Pearson test and Multiple Linear Regression test. The prevalence of mild anemia was found in $10.27 \%$ women and $5.41 \%$ men. Family support ( $b=0.09,95 \% \mathrm{CI}: 0.003-$ $0.18)$, protein intake $(b=0.41,95 \%$ CI:0.25-0.57), iron intake $(b=0.19,95 \%$ CI:0.96-0.29), vitamin $C$ intake $(b=0.10$, 95\%CI:0.02-0.41) were significantly associated with hemoglobin levels $(\mathrm{p}<0.05)$. To conclude, sufficient family support, adequate intake of protein, iron and vitamin $\mathrm{C}$ are associated to higher hemoglobin levels
\end{abstract}

Keywords: family support, macronutrient intake, micronutrient intake, hemoglobin level, Elderly.

\section{INTRODUCTION}

The main characteristic of elderly is progressive loss of physiological integrity which turns to impaired function, thus, elderly considered as being vulnerable groups of the population (Lopez-Otin et al., 2013). Based on the National Social Economic Survey (2018), Yogyakarta, Central Java, East Java, North Sulawesi, and Bali provinces occupy five top ranks for the highest percentage of the elderly, i.e., $12.37 \%, 12.34 \%$, $11.66 \%, 10.26 \%$, and $9.68 \%$ respectively.

On digestive system, aging affects all function of GI system such as motility, enzyme and hormone secretion, digestion, absorption and metabolism (Dumic et al., 2018). Morphological changes such as mucosal, glandular, and muscular atrophies also commons among elderly. Those changes may lead to a reduction of gastrointestinal function and even pathological disorders such as low appetite, chewing difficulty, and swallowing disorder (Darmojo, 2014). In addition, it leads to another health problem related to nutrient intake such as anemia. According to the study conducted by Bach et al. (2014) with total sample 19,758 elderlies found the prevalence of anemia was pretty high as much $21,1 \%$ with $17,4 \%$ classified as mild, $60,3 \%$ as moderate, and $21,8 \%$ as severe. Nutritional deficiencies such as protein and iron were identified as the most possible causes of functional iron deficiency (Liu \& Kaffes, 2012). Anemia in elderly could increase risk of death hazard ratio (HR) by 4.29 , first cardiovascularspecific hospitalization $(\mathrm{HR}=2.49)$ (Culleton et al., 2006), and dementia (HR = 1.64) (Hong et al., 2013).

In addition, limitless on nutrient intake could be possibly caused by mobility impairment. Many elderlies have limitless mobility so they require supports from their spouse, children, and other family members in providing their daily physical and psychological needs include their nutrient intake (Indonesian Statistic Centre, 2017). A recent study has indicated that family support ( $p$ $=0.002)$ and family character $(p=0.003)$ were 
significantly related with nutritional compliance among elderly (Nazari et al., 2016). Therefore, family support plays as an important role in maintaining their health and quality of life in order to remain active and productive (Hanim \& Lestari, 2018a). Moreover, adequate nutrition is required for the elderly to keep their cellular turn over and inhibition of the ageing process (Fatmah, 2010).

From these viewpoints, authors aimed to investigate the association of the family support and daily consumption of protein, iron, and vitamin $\mathrm{C}$ with hemoglobin level in elderly.

\section{METHOD}

This observational analytic study with crosssectional design was conducted at two elderly integrated health services or called Pos Pelayanan Terpadu (Posyandu) in Kenaiban Village, Juwiring District, Klaten Regency, and Gemolong Village, Gemolong District, Sragen Regency. The Posyandu in these districts has completed services with a 5-table system in accordance with national standards, issued by the Indonesian Minister of Health no. 67 year 2015.

Subject of this study was elderly aged 60-79 years old. We chose those population age because previous study mentioned that people aged $>79$ years most likely to have a memory dysfunction which could be potential bias for a study (Pengpid et al., 2019). The sample size of this study was calculated using OpenEpi 3.01 program (www. openepi.com) for cross-sectional design (sample size portion) with population size of elderly aged 60-79 years old from two regencies, set up 25\% anticipated $\%$ frequency (p), 5\% confidence limits as $+/$ - percent of 100 (d), and 1.0 design effect for complex sample surveys-DEFF for random sampling according to the sample size formula in OpenEpi. Total population in this study was 314,971 elderly $>60$ years in Klaten and Sragen district. Based on OpenEpi calculation, the minimum sample was 167 subjects with $10 \%$ adjusted for loss to follow up required. Random sampling was carried out when selecting the posyandu and 2 posyandu was selected (Posyandu Lansia Ngudi Utomo and Posyandu Among Rogo). From those two selected Posyandu, sample was chosen based on inclusion and exclusion criteria.
The inclusion of this study was elderly aged 60-79 years, did not experienced both chronic or acute disease for the past 3 months, visited Posyandu at least once a month during the past 3 months, did not have severe mobility impairment, and live with at least one member of family. While the elderly who had a history of blood transfusion within the last 4 weeks, who were on medical treatment or consume food supplements routinely in the last 1 month were excluded from this study. The research protocol was approved by the Health Research Ethics Committee, Faculty of Medicine, University of Sebelas Maret, Surakarta (Reg No. 006 / UN27.06 / KEPK / EC / 2020). Before conducting data collection, all selected subjects received detailed research information and agreed to the informed consent for those who participate in this study.

A total of 140 elderly women and 45 elderly men were interviewed for their daily food intake by using 24 -hour food recall questionnaire. $2 \times 24$ food hours recall was collected by enumerator team on non-consecutive days including weekday and weekend to reduce the potential of memory bias during recall and confirmation to the subject's companion or family by comparing the answer of subjects and their companion. The daily food intake of subjects was then calculated by using NutriSurvey program for windows SEAMEO-TROPMED RCCN University of Indonesia copyright (C2007 then classified into adequate intake with cut-off point above $77 \%$ for micronutrient (Gibson, 2008) and above $90 \%$ for protein (Supariasa et al., 2016).

Family support in fulfilling healthy nutritious food data were collected using a modified questionnaire which already tested for its validation and reliability (Hanim \& Lestari, 2018b). There are 17 questions in the family support in fulfilling healthy nutritious foods questionnaire. Questionnaire for family support in fulfilling healthy nutritious food is a closed ended/yes-no questions consist of aspect in subject's families financial assistance for living expenses (meals), assistance for accessed food (groceries), preparing food and cooking food, attention for providing main meals and snacks when the elderly are sick, evaluates the number, types and frequency of main meals including dishes and fruit in a day. Every 
"yes" answer will be given score 1 and each "no" answer will be given score 0. Family support in fulfilling healthy nutritious food classified into "sufficient family support" if the total score was $>9$, and score $\leq 9$ classified into "insufficient family support".

Blood samples were drawn from their lower arms and then collected into blood tubes containing EDTA anticoagulant and sent to a directed clinical laboratory. At the clinical laboratory, the hemoglobin levels were directly measured by using a routine method for hematological analysis (Cyanmethhemoglobin method). In brief, $20 \mu \mathrm{L}$ venous bloods was reacted with $50 \mathrm{~mL}$ Drabkin's reagents and then read spectrophotometrically at $540 \mathrm{~nm}$ light absorbance.

Lastly, categorical data, were presented as frequency and percentage whereas numeric data were presented as mean \pm standard deviation. Bivariate variable was analyzed by using Pearson association with $\mathrm{p}$-value $<0.25$ considered as significant. The variables were subsequently analyzed by using the multiple linear regression tests with $p$-value $<0.05$.

\section{RESULTS AND DISCUSSION}

The main characteristics of 185 subjects were shown in Table 1. The mean age was $67.54 \pm 5.33$ years old and $78.38 \%$ among them were women. Most subjects (82.16\%) lived with their extended family which means the elderly not only live with their husband/ wife but also living together with their children, children in law, grandchild or other relatives who become their caregiver. Most of elderly had low formal education $(83.25 \%)$. Majority of subjects $(64.86 \%)$ received monthly income not only from their children/grandchildren but also from their own business and retired wage. However, their income remained lower than the minimum regional wag established by local governments (<IDR 1.7 million) and $88.11 \%$ of subjects spent their allowance on food expenditure for about IDR600,000 - 900,000 per month.

Based on the results presented in Table 2, the mean hemoglobin level was $13.15 \pm 1.00 \mathrm{~g} /$ $\mathrm{dl}$ and mild anemia was found in $10.27 \%$ women and $5.41 \%$ men. The prevalence of anemia in elderly was lower than the national prevalence. In
Indonesia, the proportion of anemia in the $>45$ year-old age group has been increasing during the last years (Kementrian Kesehatan RI, 2013a). For elder people aged $>60$ years, the anemia prevalence in Indonesia is $46.3 \%$ (Kementrian Kesehatan RI, 2013b). Comparing to the data from The National Health and Morbidity Survey (NHMS) in 2015 carried out by Malaysian Ministry of Health, anemia prevalence in elderly aged $\geq 60$ years old was $35.3 \%$ (Yusof et al., 2018). Difference results of this study with 2 previous study mentioned might be cause by the number of the sample. The national prevalence observed samples from all of province with more large numbers of samples size, while the samples of this study was chosen from only 2 Poysandu in 2 districts. In addition, in both national prevalence, there were no age limitation of samples, but in this study, the subject was limited to age 79 years. This study also excluded the elderlies who suffered both chronic or acute disease and mobility impairments. It could be said that this study only included healthy elderly.

Based on the results presented in Table 2, the results of the categorical data of food recall shown that majority of subject were having adequate protein, iron and vitamin $\mathrm{C}$ intake. The intake of protein and iron of subjects was obtained from chicken, chicken eggs, fish, milk, tofu, tempeh, tempe gembus, peanuts and soybeans. While vitamin $\mathrm{C}$ and other vitamin were obtained from vegetable and fruit consumption such as spinach, kale, moringa leaves, papaya leaves, cassava leaves, mustard greens, cabbage, eggplants, long beans, sprouts, chayote, young papaya, carrot, beans, pumpkin, mushroom, banana, papaya, orange, watermelon. Sources of protein and fruit are consumed 2-3 times a day, while vegetables are consumed 3 times a day. Subject's food frequencies shown that majority subjects had consumed diverse food which are source of heme and non-heme iron, protein, and vitamin $\mathrm{C}$.

Family support in fulfilling healthy nutritious foods of this study includes several aspects such as (1) financial assistance, (2) access to food (groceries, prepare, cooking meals), (3) motivation to eat and prepare food when sick, (4) attention to meal schedule, (5) attention to snacking schedule and (6) eating assistance/companion. Financial assistance refers to provision of material resources 
especially healthy and nutritious food for the elderly by family members (Silva et al., 2014). The results of this study shown that $90.27 \%$ subjects got the financial assistance from their children, grandchildren, or other relatives. Aspects access to food (groceries, prepare, cooking meals) refers to how's family member provide meals start from groceries, preparation, and cooking a healthy and nutritious meals for the elderly. Many elderlies with mobility impairment might be difficult to go to grocery stores, prepare and cooking by their own. So, family support as their caregiver plays an important role to ensure the elderly have an adequate intake (Kim \& Jin, 2018). In this study, majority of subjects $(76.76 \%)$ did not go to grocery, prepare, and cooking by their own. Study of Kim \& Jin (2018) in Korea among 2904 subjects age 65-84 years shown that the elderly who live alone have a lower health status and nutritional status than elderly living with their family $(\mathrm{p}<0.05)$. The elderly who live alone or did not supported by their family also experienced oral health disorder, dysphagia, more loose tooth which make their intake insufficient.

Aspect of motivation to eat and prepare food when sick refers to attention from family member as caregiver. This included provide assistance and material needs such as healthy foods, and medicine. Most of subjects $(81.08 \%)$ in this study got more attention and affection when sick including fed motivation and assistance. Study of Locher et al. (2005) among 50 elderlies with chronic or acute disease whose hospitalized in Geriatric Hospital of Alabama University shown that the elderly who companied, fed motivated and fed up by their family member consumed $114 \mathrm{Kcal}$ more than the elderly who ate by their own ( $p=0.009)$.

Aspect of attention to meal and snacking schedule refers to how family member ensured that the elderly had their meals and snack on schedule and finish the food. In this study, most of family member of subjects $(80.54 \% ; 81.62 \%)$ did not clearly pay attention to meal and snacking schedule. Elderly who live alone tend to skip meals or snack or did not finished their food (Jamieson \& Simpson, 2013). Study of Sidenvall et al. (2000) in Upsala University among 159 subjects aged $>60$ years shown that the elderly who live alone when their husband/ wives died or left by their children after got married made them lost their appetite and motivation to eat. Low appetite and motivation to eat can affects inadequate daily intake such as protein, iron, folate which then, leads to anemia (Zhang et al., 2018). Elderly with anemia have higher risk of mortality (Corona et al., 2017).

Aspect of eating assistance/ companion refers to family member habit to eating together with the elderly. In this study, half of subjects (56.21\%) eat by their own without anyone companion. Study of Kimura et al. (2012) among elderly $>65$ years in Japan shown that elderly who eat alone have lower score of quality of life (QOL) than elderly who eat together with their family $(58.5 \pm 22.7$ vs $62.2 \pm$ 21.1, $\mathrm{p}=0.019$ ). 
Table 1. Basic characteristics of subjects

\begin{tabular}{|c|c|c|c|}
\hline Characteristics & $n=185$ & $\%$ & Mean \pm SD \\
\hline Age (years) & & & $67.54 \pm 5.33$ \\
\hline \multicolumn{4}{|l|}{ Gender } \\
\hline Man & 40 & 21.62 & \\
\hline Woman & 145 & 78.38 & \\
\hline \multicolumn{4}{|l|}{ Family Type } \\
\hline Nuclear family & 33 & 17.84 & \\
\hline Extended family & 152 & 82.16 & \\
\hline \multicolumn{4}{|l|}{ Education } \\
\hline No education & 79 & 42.71 & \\
\hline Elementary School & 75 & 40.54 & \\
\hline Junior High School & 17 & 9.19 & \\
\hline Senior High School & 8 & 4.32 & \\
\hline College & 6 & 3.24 & \\
\hline \multicolumn{4}{|l|}{ Income Source } \\
\hline Children/grandchildren & 42 & 22.70 & \\
\hline Own business & 10 & 5.41 & \\
\hline Retired salary & 13 & 7.03 & \\
\hline Combination of three sources & 120 & 64.86 & \\
\hline \multicolumn{4}{|l|}{ Total Income } \\
\hline$<$ IDR 1.7 million & 126 & 68.11 & \\
\hline$\geq$ IDR 1.7 million & 59 & 31.89 & \\
\hline \multicolumn{4}{|l|}{ Food Expenditure/month } \\
\hline IDR $600,000-900,000$ & 163 & 88.11 & \\
\hline$>$ IDR 900,000 & 22 & 11.89 & \\
\hline
\end{tabular}

Table 2. Frequency Distribution of Hemoglobin Levels, Family Support, Protein and Micronutrient Intake

\begin{tabular}{|c|c|c|c|}
\hline Characteristics & $n=185$ & $\%$ & Mean \pm SD \\
\hline \multicolumn{4}{|l|}{ Hemoglobin level (g/dl) } \\
\hline Moderate anemia $(8-10.9 \mathrm{~g} / \mathrm{dl})$ & 1 & 0.54 & \\
\hline \multicolumn{4}{|l|}{ Mild Anemia } \\
\hline Women $(11-11.9 \mathrm{~g} / \mathrm{dl})$ & 19 & 10.27 & \\
\hline Men $(11-12.9 \mathrm{~g} / \mathrm{dl})$ & 10 & 5.41 & \\
\hline \multicolumn{4}{|l|}{ Normal } \\
\hline Women $(\geq 12$ g/dl) & 125 & 67.57 & \\
\hline $\operatorname{Men}(\geq 13 \mathrm{~g} / \mathrm{dl})$ & 30 & 16.22 & \\
\hline \multicolumn{4}{|l|}{ Family support } \\
\hline \multicolumn{4}{|l|}{ Financial assistance } \\
\hline Yes & 167 & 90.27 & \\
\hline No & 18 & 9.72 & $1215+10$ \\
\hline \multicolumn{4}{|c|}{ Access to food (groceries, prepare, cooking meals) } \\
\hline Yes & 142 & 76.76 & \\
\hline No & 43 & 23.24 & \\
\hline \multicolumn{4}{|c|}{ Motivation to eat and prepare food when sick } \\
\hline Yes & 150 & 81.08 & \\
\hline No & 35 & 18.91 & \\
\hline \multicolumn{4}{|l|}{ Attention to meal schedule } \\
\hline Yes & 36 & 19.45 & \\
\hline No & 149 & 80.54 & \\
\hline \multicolumn{4}{|l|}{ Attention to snacking schedule } \\
\hline Yes & 34 & 18.37 & \\
\hline No & 151 & 81.62 & \\
\hline
\end{tabular}




\begin{tabular}{|c|c|c|c|}
\hline Characteristics & $n=185$ & $\%$ & Mean \pm SD \\
\hline \multicolumn{4}{|l|}{ Eating assistance/companion } \\
\hline Yes & 81 & 43.78 & \\
\hline No & 104 & 56.21 & \\
\hline \multicolumn{4}{|l|}{ Nutrient Intake } \\
\hline \multicolumn{4}{|l|}{ Iron } \\
\hline Adequate ( $\geq 77 \% \mathrm{AKG})$ & 88 & 47.6 & \\
\hline Inadequate $(<77 \% \mathrm{AKG})$ & 97 & 52.4 & \\
\hline \multicolumn{4}{|l|}{ Vitamin C } \\
\hline Adequate $(\geq 77 \% \mathrm{AKG})$ & 185 & 100.0 & \\
\hline \multicolumn{4}{|l|}{ Protein } \\
\hline Adequate ( $\geq 90 \% \mathrm{AKG})$ & 152 & 82.2 & \\
\hline Inadequate $(<90 \% \mathrm{AKG})$ & 33 & 17.8 & \\
\hline
\end{tabular}

This study also found elderly who eating alone have lower food diversity (score FDSK-11 9.9 \pm 1.3 vs $10.2 \pm 1.3 ; \mathrm{p}=0.002$ ) and lower BMI score. Based on Table 3, the average value of family support in fulfilling healthy nutritious foods is $10.69 \pm 3.80$. Based on numerical data, the average subject's daily intake compared to Indonesian recommended dietary allowance for the elderly people were $97.7 \%, 97.5 \%, 78.5 \%$, of subjects consumed adequate protein, vitamin $\mathrm{C}$, and iron respectively.

Table 3. Association of Family Support, Protein Intake and Micronutrient Intake with Hemoglobin Levels

\begin{tabular}{lccccc}
\hline \multicolumn{1}{c}{ Variables } & Mean \pm SD & RDA & \% RDA & r & p \\
\hline Family Support (score) & $10.69 \pm 3.80$ & - & - & 0.64 & $<0.001$ \\
Protein intake (g/day) & $56.56 \pm 2.67$ & 58 & 97.7 & 0.78 & $<0.001$ \\
Vitamin C intake (mg/day) & $73.28 \pm 1.85$ & 75 & 97.5 & 0.78 & $<0.001$ \\
Iron intake (mg/day) & $6.28 \pm 2.01$ & 8 & 78.5 & 0.78 & $<0.001$ \\
\hline
\end{tabular}

*RDA $=$ Indonesia Recommended Dietary Allowance $(\mathrm{AKG}, 2019)$

Table 4. Multiple Linear Regression Test of Sociodemographic, Family Support, Protein and Micronutrient with Hemoglobin Levels

\begin{tabular}{lcccc}
\hline \multicolumn{1}{c}{ Variables } & Unstandardized Coefficients B & Standardized Coefficients Beta & $\mathbf{9 5 \% C I ~}$ & $\boldsymbol{p}$ \\
\hline Model 1 & & & & \\
Family Support & 0.093 & 0.124 & $-0.026-0.160$ & 0.015 \\
Protein Intake & 0.321 & 0.329 & $0.195-0.448$ & $<0.001$ \\
Iron intake & 0.238 & 0.319 & $0.141-0.335$ & $<0.001$ \\
Vitamin C Intake & 0.10 & 0.19 & $0.001-0.16$ & 0.048 \\
Model 2 & & & & \\
Age & -0.151 & -0.195 & $-0.246-(-0.056)$ & 0.002 \\
Gender & -0.151 & -0.166 & $-0.299-(-0.003)$ & 0.045 \\
Residence Status & 0.066 & 0.023 & $-0.55-0.187$ & 0.285 \\
Education & 0.043 & 0.089 & $-0.014-0.082$ & 0.163 \\
Family Support & 0.093 & 0.124 & $0.003-0.183$ & 0.044 \\
Protein Intake & 0.409 & 0.419 & $0.250-0.567$ & $<0.001$ \\
Iron intake & 0.193 & 0.049 & $0.96-0.289$ & $<0.001$ \\
Vitamin C Intake & 0.102 & 0.170 & $0.020-0.413$ & 0.043 \\
\hline
\end{tabular}

*Adjusted R Square Model $1=0.541$

Adjusted R Square Model $2=0.603$ 
Table 3 revealed that family support, protein, and micronutrient intake (vitamin $\mathrm{C}$ and iron) were positively correlated with hemoglobin levels ( $p$ $<0.001)$. The association was observed in daily intake of family support with $\mathrm{r}=0.64$, protein, vitamin $\mathrm{C}$ and iron with $\mathrm{r}=0.78$. Additionally, all variables had moderate association with hemoglobin levels.

Further analysis using multiple regression linier test was performed to evaluate association all variables together with hemoglobin levels. Based on Table 4 (Model 2), residence status and education did not associated with hemoglobin levels in the elderly aged 60-79 years old. Age $(b=-0.151,95 \%$ CI: $-0.246-(-0.056)$, gender $(b=-0.151,95 \%$ CI: $-0.299-(-0.003)$ significantly associated with better hemoglobin level with $\mathrm{p}<$ 0.05 .

Based on Table 4, family support, protein and micronutrient intake were positively associated with hemoglobin levels among elderly aged 6079 years old. Family support $(b=0.093,95 \% \mathrm{CI}$ : 0.003- 0.183$)$, protein intake $(b=0.409,95 \% \mathrm{CI}$ : 0.250 - 0.567), iron intake ( $b=0.193,95 \%$ CI: 0.96 -0.289 ), vitamin C intake ( $b=0.102,95 \%$ CI: 0.020 0.413 ) significantly increased hemoglobin level with $\mathrm{p}<0.05$.

Furthermore, protein intake $(\mathrm{B}=0.42)$ was the strongest factors that associated hemoglobin levels. Altogether, four variables contributed to $54.1 \%$ hemoglobin levels in elderlies while $45.9 \%$ hemoglobin levels were affected by other factors. In the 2nd model regression, basic characteristic of subject was analyzed and reveals an association of age $(\mathrm{p}=0.002)$ and gender $(p=0.045)$ with hemoglobin levels, while residence status $(\mathrm{p}=0.258)$ and formal education were not associated with hemoglobin levels $(\mathrm{p}=0.163$ ). Eight variables contributed to $60.3 \%$ hemoglobin levels in elderly while $39.7 \%$ hemoglobin levels were affected by other factors, which also means basic characteristic age, gender, education, and residence status were only contribute $6.2 \%$ to hemoglobin levels.

In elderly, many degenerative morphologic changes occurred, such as digestive changes and make easier to lose teeth. Atrophic changes also occur in the mucosa, glands and digestive muscles causing functional changes to pathological changes, including chewing and swallowing disorders and appetite alteration (Darmojo, 2014). Impairment function of digestive organs and glands causes the need of food that easily digested (Sediaoetama, 2010). If the nutritional needs of the elderly cannot be fulfilled because of a decrease in the digestive tract function, especially in a long time, can cause iron deficiency anemia. Iron deficiency anemia is anemia that occurs due to lack of nutrients, namely calories, protein and iron (Clark, 2009).

Iron was minerals that are involved in erythropoiesis. Vitamin $\mathrm{C}$ is a factor that can enhance the absorption of heme and non-heme iron because it has the ability to reduce $\mathrm{Fe} 3+$ to $\mathrm{Fe} 2+$ through the intestinal brush border surface (Zhu et al., 2017). It is clearly indicated that our main findings support the existing theories, which iron and vitamin $\mathrm{C}$ consumption plays an important role in iron non-heme absorption in small intestine for hemoglobin production (Fuqua et al., 2012; Collins et al., 2012; Sharp, 2010).

The elderly in this study seem to consume more non-heme iron derived from tofu, tempeh and vegetables rather than livestock products because $88.11 \%$ among them spent IDR 20,000 - 30,000 per day to buy non-heme iron food. Furthermore, tofu, tempeh, and vegetables price in Central Java, Indonesia is cheaper than meat product price. In contrast to our results, 255 people who aged $\geq 60$ years from 30 clusters village in Nainital District, Uttarakhand State, India showed that $42 \%$ and $72 \%$ among them had inadequate intake of vitamin $\mathrm{C}$ and iron intake respectively (Gupta et al., 2017).

A recent study carried out by Gupta et al. (2020) in the same district and state, India has also revealed moderate and severe anemia observed in 985 elderly who consumed significantly low daily consumption of iron $(p<0.001)$, vitamin $C$, copper, and manganese $(\mathrm{p}<0.01)$ compared to the elderly with normal and mild anemia. The discrepancy of these results is probably caused by the population number, our study was only 185 compared to those study with 985 samples. Another reason is adequate vitamin $\mathrm{C}$ intake in our study is much higher than Gupta's study (100\% vs. $28 \%$ ) whereas adequate intake of iron is comparable $(47.6 \% \mathrm{vs}$. $42.0 \%)$.

The limited number of subjects and Posyandu chosen from 2 district in this study 
might become a limitation. However, hemoglobin levels measurement using hematological analysis (Cyanmethhemoglobin method) from venous in lower arm rather than simple kit $\mathrm{Hb}$ measurement from the blood of fingertip could be one of the study strength.

\section{CONCLUSION}

In conclusion, low anemia prevalence was found in elderly aged 60-79 years old in Klaten and Sragen Regencies. Daily intake of iron, vitamin $\mathrm{C}$, protein, and family support associated with hemoglobin levels. Families should be supports in terms of access to food, processing and preparation of food as well as monitoring the intake of healthy and nutritious food in the elderly to prevent anemia. Nutrition education for elderly families is also needed to increase knowledge of providing healthy guidelines, nutritiously balanced food, clean and healthy lifestyles that will support elderly's health. Related stakeholders also need to provide additional food program for improve nutrient intake of elderly.

\section{REFERENCES}

Bach, V., Schruckmayer, G., Sam, I., Kemmler, G., Stauder, R. (2014). Prevalence and Possible Causes of Anemia in The Elderly: A CrossSectional Analysis of A Large European University Hospital Cohort. Clin Interv Aging, 9, 1187-1196.

Clark, S.F. (2009). Iron Deficiency Anemia: Diagnosis and Management. Gastroenterology, $25,122-128$

Collins, J.F., Anderson, G.J. (2012). Intestinal Iron Absorption. In: Johnson LR, Ghishan FK, Kaunitz J, Merchant JL, Said HM, Wood JD, editors. Physiology of the gastrointestinal tract: 5th Ed. New York: Elsevier, 1921-1947.

Corona, L.P., de Oliveira Duarte, Y.A., Lebrão, M.L. (2017). Markers of Nutritional Status And Mortality In Older Adults: The Role Of Anemia And Hypoalbuminemia. Geriatr Gerontol Int, 1-6.

Culleton, B.F., Manns, B.J., Zhang, J., Tonelli, M., Klarenbach, S., Hemmelgarn, B.R. (2006). Impact of Anemia on Hospitalization and Mortality in Elderly. Blood, 107 (10), 38413846 .
Darmojo, B.R. (2014). Geriatri (Ilmu Kesehatan Usia Lanjut); 5th ed. Jakarta: Balai Penerbit FK UI.

Dumic, I., Nordin, T., Jecmenica, M., Lalosevic, M.S., Milosavljevic, T., Milovaconic, T. (2018). Gastrointestinal Tract Disorder in Older Age. Canadian Journal of Gastroenterology and Hepatology, 1-19.

Fatmah. (2010). Gizi Usia Lanjut. Jakarta: Erlangga.

Fuqua, B.K., Vulve, C.D., Anderson, G.J. (2012). Intestinal Iron Absorption. Journal of Trace Elements in Medicine and Biology, 26, 115119.

Gibson, R.S. (2008). Principles of Nutritional Assessment. 2nd Ed. UK: Oxford University Press Inc.

Gupta, A., Khenduja, P., Pandey, R.M., Sati, H.C., Sofi, N.Y., Kapil, U. (2017). Dietary Intake of Minerals, Vitamins, and Trace Elements Among Geriatric Population in India. Biol Trace Elem Res, 1-11.

Gupta, A., Ramakrishnan, L., Pandey, R.M., Sati, H.C., Khandelwal, R., Khenduja, P., Kapil, U. (2020). Risk Factors of Anemia amongst Elderly Population Living at High-Altitude Region of India. Journal of Family Medicine and Primary Care, 9(2), 673-682.

Hanim, D. dan Lestari, A. (2018a). Implementasi Model Integratif Promosi Gizi Kesehatan Berbasis Status Sosial Ekonomi Keluarga Untuk Peningkatan Kualitas Hidup Lanjut Usia. Surakarta: Pusat Studi Penelitian dan Pengembangan Pangan Gizi dan Kesehatan Masyarakat Universitas Sebelas Maret.

Hanim, D. dan Lestari, A. (2018b). Panduan Kuesioner: Promosi Gizi Kesehatan, Dukungan Keluarga, Kelompok Sebaya, Lembaga Komunitas dan Kualitas Hidup Lanjut Usia. Surakarta: Program Studi Ilmu Gizi Pascasarjana Universitas Sebelas Maret.

Hong, C.H., Falvey, C., Harris, T.B. (2013). Anemia and Risk of Dementia in Elderly: Findings from The Health ABC Study. Neurology, 81(10), 939.

Indonesian Statistic Centre. (2017). Statistik Penduduk Lanjut Usia 2017. Jakarta: Subdirektorat Statistik Pendidikan dan Kesejahteraan Sosial.

Jamieson, L. \& Simpson, R. (2013). Living Alone, Globalization, Identity and Belonging. New York: Palgrave Macmillan. 
Kementerian Kesehatan RI. (2013a). Riset Kesehatan Dasar (Riskesdas). Jakarta: Badan Penelitian dan Pengembangan Kesehatan Kemenkes RI.

Kementrian Kesehatan R.I. (2013b). Gambaran Kesehatan Lanjut Usia di Indonesia. Jakarta: Pusat Data dan Informasi Kementrian Kesehatan RI.

Kim, E.J. \& Jin, B.H. (2018). Comparison Of Oral Health Status And Daily Nutrient Intake Between Elders Who Live Alone And Elders Who Live With Family: Based On the Korean National Health And Nutrition Examination Survey (KNHANES VI) (2013-2015). Gerodontology, 00, 1-10.

Kimura, Y., Wada, T., Okumiya, K., Ishimoto, Y., Fukutomi, E., Kasahara, Y., et al. (2012). Eating Alone Among Community-Dwelling Japanese Elderly: Association with Depression and Food Diversity. The Journal of Nutrition, Health \& Aging, 16(8), 728-731.

Koury, M.J., Ponka, P. (2004). New Insights into Erythropoiesis: The Roles of Folate, Vitamin B12, And Iron. Annu Rev Nutr, 24, 105-31.

Liu, K. \& Kaffes, A.J. (2012). Iron Deficiency Anemia: A Review Of Diagnosis, Investigation And Management. Eur J Gastroenterology Hepatology, 24(2), 109-16.

Locher, J.L., Robinson, C.O., Roth, D.L., Ritchie, C.S., Burgio, K.L. (2005). The Effect of the Presence of Others on Caloric Intake in Homebound Older Adults. Journal of Gerontology: Medical Sciences, 60A(11), 1475-1478.

Lopez-Otin, C., Blasco, M.A., Patridge, L., Serrano, M., Kroemer, G. (2013). Hallmarks of aging. Cell, 153(6), 1194-1217.

Nazari, N., Yusuf, R., Tahlil, T. (2016). Dukungan dan Karakteristik Keluarga dengan Pemenuhan Gizi pada Lansia. Jurnal Ilmu Keperawatan, 4 (2), 75-86.

Pegpid S, Peltzer K, Susilowati IH. (2019). Cognitive Functioning and Associated Factors In Elderly: Results from the Indonesian Family
Life Survey-5 (IFLS-5) In 2014-2015. Current Gerontology And Geriatrics Research, 2019, 1-7.

Peraturan Menteri Kesehatan Republik Indonesia Nomor 67 Tahun 2015 Penyelenggaraan Pelayanan Kesehatan Lanjut Usia Di Pusat Kesehatan Masyarakat. 12 Oktober 2015. Jakarta: Berita Negara Republik Indonesia Tahun 2015 Nomor 1663.

Sediaoetama, A.D. (2010). Ilmu Gizi Untuk Mahasiswa dan Profesi. Jilid I. Dian Rakyat. Jakarta.

Sharp, P.A. (2010). Intestinal Iron Absorption: Regulation by Dietary and Systemic Factors. Int J Vitam Nutr, 80, 231-42.

Sidenvall, B., Nydahl, M., Fjellström, C. (2000). The Meal as A Gift- the Meaning of Cooking Among Retired Women. Gerontology, 19(4), 405-423.

Silva, I.T., Junior, E.P.P., Vilela, A.B.A. (2014). Self-Concept of Health of Elderly Living with Relatives. Revista Brasileira de Geriatria e Gerontologia, Rio de Janeiro, 17, 220-225.

Supariasa, I.D.N., Bakri, B., Fajar, I. (2016). Penilaian Status Gizi. Edisi Kedua. Jakarta: EGC.

World Health Organization. (2011). Haemoglobin Concentrations for The Diagnosis of Anaemia and Assessment of Severity. Vitamin and Mineral Nutrition Information System. Geneva: WHO.

Yusof, M., Awaluddin, S.M., Omar, M., Ahmad, N.A., Aziz, F.A.A., Jamaluddin, R., Aris, T., et al. (2018). Prevalence of Anaemia Among the Elderly in Malaysia and It's Associated Factors: Does Ethnicity Matter?. Journal of Environmental and Public Health, 1-10.

Zhang, Q., Qin, G., Liu, Z., Li, Z., Li, J., Varma, D.S., et al. (2018). Dietary Balance Index-07 and the Risk of Anemia in Middle Aged and Elderly People in Southwest China: A Cross Sectional Study. Nutrient, 10, 162.

Zhu, S., Hu, J., Efird, J.T. (2012). Role of Social Support In Cognitive Function Among Elders. Journal of Clinical Nursing, 21, 2118-2125 